ISSN 1392-3196 / e-ISSN 2335-8947

Zemdirbyste-Agriculture, vol. 107, No. 3 (2020), p. 217-226

DOI 10.13080/z-a.2020.107.028

\title{
Effect of catch crop, straw management and fertilisation on the productivity of field pea and winter wheat crop sequence
}

\author{
Ausra ARLAUSKIENE ${ }^{1}$, Jurgita CESEVICIENE², Alvyra SLEPETIENE ${ }^{2}$ \\ ${ }^{1}$ Joniškèlis Experimental Station, Lithuanian Research Centre for Agriculture and Forestry \\ Joniškèlis, Pasvalys distr., Lithuania \\ ${ }^{2}$ Institute of Agriculture, Lithuanian Research Centre for Agriculture and Forestry \\ Instituto 1, Akademija, Kèdainiai distr., Lithuania \\ E-mail: jurgita.ceseviciene@lammc.lt
}

\begin{abstract}
The present study aimed to determine the effect of catch crop, straw management and mineral fertilisation on the grain yield and chemical composition of field pea (Pisum sativum L.) and winter wheat (Triticum aestivum L.) on a clay loam (Endocalcari Endohypogleyic Cambisol) (siltic, drainic). The following crop sequence was studied: spring barley (Hordeum vulgare L.) + white mustard (Sinapis alba L.) as a catch crop or without it $\rightarrow$ semi leafless field pea $\rightarrow$ winter wheat. The following management practices were applied: the straw of barley was either removed from the field or retained (chopped and spread); white mustard as a catch crop was incorporated into the soil. Different fertilisation levels were investigated: unfertilised, sustainable and intensive. The retention of barley straw $\left(+\mathrm{N}_{30}\right)$ resulted in significantly higher soil mineral nitrogen (SMN) content (on average 13.8\%) in spring. Negative significant interaction of white mustard cultivation and fertilisation on SMN content in the soil was determined. The decrease in SMN and $\mathrm{N}-\mathrm{NO}_{3}$ resulted in better formation of pea yield components and grain yield. The highest crude protein content was detected in the pea grain, when white mustard mass had been incorporated into the soil and barley straw had been removed from the field. During the second year, white mustard cultivation, straw application as fertiliser and mineral fertilisation had a significant positive effect on SMN content. Winter wheat grain yield was significantly increased by white mustard cultivation (on average $4.9 \%$ ) and mineral fertilisation (sustainable fertilisation $-55.3 \%$, intensive fertilisation $-64.5 \%$ ). Increased fertilisation intensity gave an increase in winter wheat grain crude protein content but smaller amounts of PK in grain. The retention of straw resulted in significant increase in grain crude protein content in sustainable fertilisation treatments, but in decrease in grain PK content in all fertilisation treatments. A positive effect of white mustard was found on grain phosphorus $(\mathrm{P})$ accumulation but negative effect on grain potassium $(\mathrm{K})$ accumulation.
\end{abstract}

Key words: protein and PK content of grains, soil mineral N, white mustard, yield components, yield.

\section{Introduction}

Due to the increase in the area sown to cereals and oil crops in many European Union (EU) countries, the production of legume crops and their role in crop rotation systems have significantly decreased (Voisin et al., 2014; Magrini et al., 2016). This is a consequence of an agrochemical paradigm, public policies and market dynamics that promote cereals. Worldwide, soybean is the dominant crop legume, representing 50\% of the global crop legume area and $68 \%$ of global production (Herridge et al., 2008). Meanwhile, the EU (except for Italy) has mainly cultivated field pea (Pisum sativum L.) and field bean (Vicia faba L.) (Magrini et al., 2016). However, in order to reduce the dependence on imported material (particularly soya bean meal) from the American continents and increase biodiversity according to the EU greening programme, some legume species have good prospects.
Grain legumes have many functional and nutritional properties, both as feed and food (Voisin et al., 2014; Magrini et al., 2016). However, as the number of livestock decreases, the demand for protein feed decreases as well. In addition, the yield $\left(\mathrm{kg} \mathrm{ha}^{-1}\right)$ of protein from perennial forage legumes is higher than that of grain legumes. In human nutrition, these plants account for only a small proportion of the diet, although the structure and composition of their seeds provide a physiologically favourable matrix for general nutrition (Pilorgé, Muel, 2016). Legumes have rarely been used to provide feedstock for the emerging bio-based economies (Bedoussac et al., 2015) - bioenergy, biomaterial and biochemical production (Langeveld et al., 2010). The wider use of grain legumes in industry could be facilitated by technologies used to fractionate legume mass for the

Please use the following format when citing the article:

Arlauskiene A., Ceseviciene J., Slepetiene A. 2020. Effect of catch crop, straw management and fertilisation on the productivity of field pea and winter wheat crop sequence. Zemdirbyste-Agriculture, 107 (3): 217-226. DOI 10.13080/z-a.2020.107.028 
production of protein, fibre and starch (Voisin et al., 2014).

The increase in wheat and rapeseed production has led to an increase in the share of legume crops in the crop structure. Crop rotations have become narrow, and their sustainability is often questioned (Reckling et al., 2016). Researchers suggest using local resources more effectively and diversifying crop rotations with legume crops (Angus et al., 2015; Gan et al., 2015; Hegewald et al., 2018). Legumes generally have lower gross margins than cereals or oilseeds, but their rotational effects (often called pre-crop, break crop or residual effects) increase the benefit of subsequent crops; therefore, the assessment of legumes needs to be performed at the cropping system scale (Gan et al., 2015; Preissel et al., 2015; Reckling et al., 2016). Under European conditions, grain legume pre-crop effects are variable, they increase cereal yields by $0.5-1.6 \mathrm{Mg} \mathrm{ha}^{-1}$ (Preissel et al., 2015; Toleikiene et al., 2019). Pre-crop effects of grain legumes depend on their productivity (Toleikienè et al., 2019) and seasonal conditions (Angus et al., 2015).

Legumes produce nitrogen $(\mathrm{N})$ through fixation and may increase soil residual and mineralizable $\mathrm{N}$, thus reducing the need for fertiliser $\mathrm{N}$ in subsequent crops (O'Donovan et al., 2014; Magrini et al., 2016). Plants of the family Fabaceae reduced the need for mineral $\mathrm{N}$ fertilisers by $25 \%$ (O'Donovan et al., 2014). The data also suggest that, in general, those countries using a higher proportion of $\mathrm{N}$ inputs from symbiotic $\mathrm{N}$ fixation rather than from synthetic fertiliser have a better $\mathrm{N}$ use efficiency (Meng et al., 2016). Grain legume pre-crops have other benefits as well: break the development cycles of cereal pests and diseases (Angus et al., 2015), conserve soil moisture (Gan et al., 2015; Hegewald et al., 2018), mobilize P (Angus et al., 2015; Hegewald et al., 2018) and help alleviate soil physical and structural problems (Hegewald et al., 2018).

Peas and faba beans are plants associated with cooler climates and fertile soils. In addition, Fabaceae plants are more susceptible to biotic and abiotic factors, compared to other plants, and often encounter several constraints simultaneously (Siddique et al., 2012). Until now, the modernisation of grain legume cultivating technologies has been slower than that of cereals and rapeseed (Magrini et al., 2016). As a result, there is a need for the development, testing and dissemination of legume cultivation technologies on national and local levels (Jensen et al., 2010; Siddique et al., 2012).

Currently, research on grain legumes is aimed at improving the availability of water and nutrients (Siddique et al., 2012), increasing $\mathrm{N}_{2}$ fixation (Herridge et al., 2008) and effectiveness of its utilisation, and increasing the yield and protein content (Jensen et al., 2010) by strengthening other qualitative parameters (Voisin et al., 2014). At present, the above-mentioned tasks are being addressed by using complex ecosystembased approaches and innovative tillage techniques (Santín-Montanyá et al., 2014), optimising the sequence of crops in rotation and phytosanitary breaks (Fuchs et al., 2014), mineral and organic fertilising systems (Jannoura et al., 2014) as well as alternative crop maintenance measures (Ebrahimi et al., 2018).

Researchers suggest using legume crops to build more diversified and more sustainable production systems (Magrini et al., 2016). Legumes should be considered as important components in the development of future agroecosystems (Reckling et al., 2016), as these plants restore ecosystem services (Jensen et al., 2015), reduce greenhouse gas emissions (Jeuffroy et al., 2013), lower the use of fossil energy (Bedoussac et al., 2015), accelerate rates of $\mathrm{C}$-sequestration in soil (Plaza-Bonilla et al., 2016) and provide a valuable source of feedstock for biorefineries. One of the keys for future sustainable agriculture is multifunctionality of systems and crops (Jensen et al., 2015).

The aim of the present study was to determine the effect of catch crop, straw management and mineral fertilisation on the grain yield and grain chemical composition of semi-leafless field pea and winter wheat on a clay loam.

\section{Materials and methods}

Site description and soil survey. The research was conducted in the northern part of Central Lithuania's Lowland $\left(56^{\circ} 12^{\prime} \mathrm{N}, 24^{\circ} 20^{\prime} \mathrm{E}\right)$ at the Joniškèlis Experimental Station of the Lithuanian Research Centre for Agriculture and Forestry. The experiment was carried out on a drained clay loam with a deeper lying sandy light loam whose parental rock is limnoglacial clay on morenic loam (Endocalcari Endohypogleyic Cambisol) (siltic, drainic) according to WRB (2014). The topsoil $(0-25 \mathrm{~cm})$ was close to neutral $(\mathrm{pH} 6.4-6.5)$, medium in phosphorus $\left(\mathrm{P}_{2} \mathrm{O}_{5} 180-187 \mathrm{mg} \mathrm{kg}^{-1}\right)$, high in potassium $\left(\mathrm{K}_{2} \mathrm{O} 267-268^{2} \mathrm{mg} \mathrm{kg} \mathrm{kg}^{-1}\right)$, moderate in humus (28.3$\left.31.4 \mathrm{~g} \mathrm{~kg}^{-1}\right)$ and total nitrogen $\left(1.50-1.53 \mathrm{~g} \mathrm{~kg}^{-1}\right)$.

Experimental design and details. The field experiment was conducted during the period 20132015 using common spring barley (Hordeum vulgare L.) without or with a catch crop $\rightarrow$ semi-leafless field pea (Pisum sativum L.) $\rightarrow$ common winter wheat (Triticum aestivum L.) crop sequence. The following experimental design was employed: Factor A. Catch crop (CC): 1) without catch crop (WCC) and 2) catch crop white mustard (Sinapis alba L.) (WM). Factor B. Straw (S) management: 1) removed from the field (WS), and 2) chopped and spread (S); Factor C. Fertilisation (F): 1) unfertilised (UF), 2) sustainable fertilising (SF) and 3 ) intensive fertilising (IF).

The experimental plots were laid out in a complete three-factor randomised block design with four replicates. Individual plot size was $5 \times 14 \mathrm{~m}$. After spring barley harvesting, straw was either removed or chopped and spread (factor $\mathrm{B}$ ). Ammonium nitrate $\left(\mathrm{N}_{30}\right)$ was applied for straw decomposition. White mustard (cultivar 'Braco', seed rate 4.5 million ha-1) was sown shortly after harvesting of spring barley and stubble cultivation (factor A). The stubble was broken twice for the plots without catch crop. Catch crop mass was chopped and in the middle of October incorporated using a disk cultivator at $10-12 \mathrm{~cm}$ depth and five days before ploughing at 24-25 cm depth.

In 2014, semi-leafless field pea (cultivar 'Tinker', seed rate 1.2 million $\mathrm{ha}^{-1}$ ), and in 2015 winter wheat (cultivar 'Ada', seed rate 5.0 million ha' ${ }^{-1}$ ) were grown. The pea straw was used according to the experimental design (without $\mathrm{N}$ ). Fertiliser rates for achieving a target spring barley, pea and winter wheat yield were calculated according to the chemical composition and properties of the soil and based on the recommendations for fertiliser rate calculation Fertilisation plan (factor C). Spring barley (cultivar 'Noja DS', seed rate 4 million ha' ${ }^{-1}$ ) was applied with the following mineral fertiliser rates: UF $-\mathrm{N}_{0} \mathrm{P}_{0} \mathrm{~K}_{0}, \mathrm{SF}-\mathrm{N}_{72} \mathrm{P}_{21} \mathrm{~K}_{12}$ (planned yield $4.0 \mathrm{t} \mathrm{ha}^{-1}$ ) and IF $-\mathrm{N}_{108} \mathrm{P}_{30} \mathrm{~K}_{15}$ (planned yield $5.5 \mathrm{t} \mathrm{ha}^{-1}$ ); pea crop: UF $-\mathrm{N}_{0} \mathrm{P}_{0} \mathrm{~K}_{0}, \mathrm{SF}-\mathrm{N}_{0} \mathrm{P}_{20} \mathrm{~K}_{1,1}$ (planned yield $3.0 \mathrm{t} \mathrm{ha}^{-1}$ ) and IF - N $\mathrm{P}_{24} \mathrm{~K}_{10}$ (planned yield $4.0 \mathrm{t} \mathrm{ha}^{-1}$ ), winter wheat: UF $-\mathrm{N}_{0} \mathrm{P}_{0} \mathrm{~K}_{0}, \mathrm{SF}-\mathrm{N}_{104} \mathrm{P}_{38} \mathrm{~K}_{0}$ (planned yield $6.0 \mathrm{t} \mathrm{ha}^{-1}$ ) and IF $-\mathrm{N}_{145} \mathrm{P}_{44} \mathrm{~K}_{18}$ (planned yield $8.0 \mathrm{t} \mathrm{ha}^{-1}$ ). The PK fertilisers 
were applied pre-sowing, and nitrogen was applied presowing or at resumption of vegetation $(67 \%)$ and at the end of booting stage (33\%). The following forms of fertiliser were used: ammonium nitrate, superphosphate and potassium chloride. In the field experiment, the crops were grown according to the conventional farming standards.

Weather conditions. The weather data were obtained from the meteorological station, located $0.5 \mathrm{~km}$ away from the experimental site (Table 1). In the first ten-day period of January, 2014 positive temperatures prevailed; only in the second half of January did a spell of colder weather occur. In February and March, the weather was changeable, and the amount of rainfall differed little from the standard climate normal (average data for 30 (1981-2010) years). The weather became warmer in the last ten-day period of March. The growing season of the year 2014 was favourable for the pea crop. April and May were warmer $\left(3^{\circ} \mathrm{C}\right.$ and $2^{\circ} \mathrm{C}$, respectively) and wetter (36.4 and $24.0 \mathrm{~mm}$, respectively), compared with the standard climate normal. This period was very important for the formation of aboveground biomass. In spring 2015, the weather was warmer and drier than usual. The summer was warm and normally humid (except August). In August, the mean daily temperature was higher $\left(2.1^{\circ} \mathrm{C}\right)$ than the standard climate normal. For the greater part of July, the weather was moderately warm and rainy. The conditions were favourable for the growth of winter wheat.

Table 1. The monthly mean precipitation and temperature (average 1981-2010) at the experimental site

\begin{tabular}{|c|c|c|c|c|c|c|}
\hline \multirow{2}{*}{ Month } & \multicolumn{3}{|c|}{ Temperature ${ }^{\circ} \mathrm{C}$} & \multicolumn{3}{|c|}{ Precipitation $\mathrm{mm}$} \\
\hline & 2014 & 2015 & $\mathrm{SCN}$ & 2014 & 2015 & $\mathrm{SCN}$ \\
\hline January & -5.2 & -1.5 & -5.8 & 29.4 & 50.6 & 30.9 \\
\hline February & 1.8 & 0.4 & -5.6 & 22.0 & 5.3 & 24.6 \\
\hline March & 5.4 & 4.2 & -1.1 & 22.0 & 39.6 & 27.3 \\
\hline April & 9.2 & 7.4 & 6.2 & 32.8 & 24.5 & 37.4 \\
\hline May & 14.3 & 11.3 & 12.3 & 82.0 & 29.9 & 45.6 \\
\hline June & 15.2 & 14.7 & 15.6 & 83.4 & 12.3 & 59.4 \\
\hline July & 20.6 & 17.2 & 17.2 & 54.5 & 75.1 & 69.2 \\
\hline August & 18.5 & 19.3 & 17.1 & 14.6 & 22.2 & 67.9 \\
\hline September & 14.2 & 13.7 & 12.0 & 8.4 & 81.8 & 57.9 \\
\hline October & 7.1 & 5.3 & 6.3 & 45.5 & 4.1 & 45.5 \\
\hline November & 2.5 & 4.2 & 1.4 & 33.1 & 41.7 & 42.7 \\
\hline December & -1.8 & 1.7 & -3.0 & 43.5 & 17.7 & 39.0 \\
\hline
\end{tabular}

$\mathrm{SCN}$ - standard climate normal

Plant and soil analyses. At the hard dough stage (BBCH 87) before crops were harvested, 25 plants per each plot were collected to determine the number of spikes per unit area (spikes $\mathrm{m}^{-2}$ ), number of grains per spike of winter wheat, the number of pods and number of grain per unit area of pea (pods $\mathrm{m}^{-2}$ and grains $\mathrm{m}^{-2}$ ). Spring barley, field pea and winter wheat grains were harvested, when the majority of plants had reached the BBCH 87 stage. Pea and winter wheat straw and grain yield were measured by weighing. The grain yield of peas and wheat was converted to standard moisture $(14 \%)$, straw - to dry matter (DM). Grain samples $(1 \mathrm{~kg})$ were taken from each plot for the determination of thousand grain weight (TGW), DM content and chemical composition. Grain samples were dried and ground using a ZM200 ultra-centrifugal mill (Retch, Germany) with $1-\mathrm{mm}$ mesh sieves and analysed for $\mathrm{N}, \mathrm{P}$ and $\mathrm{K}$ content. Grain $\mathrm{N}$ content was recalculated for crude protein by multiplying by 6.25 (pea) and 5.7 (wheat). The content of N, P and K was evaluated in the sulphuric acid digestates. Soil samples for total nitrogen determination were analysed using the Kjeldahl method with a Kjeltec system 1002 (Foss Tecator, Sweden). The content of $\mathrm{P}$ was quantified spectrophotometrically by a coloured reaction with ammonium molybdate-vanadate at a wavelength of $430 \mathrm{~nm}$ on a spectrophotometer Cary $50 \mathrm{UV}-\mathrm{Vis}$ (Varian Inc., USA). Respective K content was evaluated by atomic absorption spectrometry with an AAnalyst 200 (Perkin Elmer, USA) in accordance with the manufacturer's instructions. Soil mineral nitrogen content $\left(\mathrm{SMN}=\mathrm{N}-\mathrm{NO}_{3}+\mathrm{N}-\mathrm{NH}_{4}\right)$ in the $0-60$ $\mathrm{cm}$ layer was measured in the spring (2014) before field pea sowing and after resumption of vegetation of winter wheat (2015). Nitrate nitrogen $\left(\mathrm{N}-\mathrm{NO}_{3}\right)$ was determined by ionometric method and ammonium nitrogen $\left(\mathrm{N}-\mathrm{NH}_{4}\right)$ - by spectrophotometric method. Chemical analyses were conducted at the Chemical Research Laboratory of the Institute of Agriculture, Lithuanian Research Centre for Agriculture and Forestry.
Statistical analysis was performed using the software package SELEKCIJA (Raudonius, 2017). The differences in research data between the factors (catch crop, straw management and fertilisation) and their interactions were considered significant according to $p$-values $<0.05$, when three-way analysis of variance (ANOVA), version 3.1 was used followed by Fisher's criteria $(F)$. After that, the factors marked as significant (by $p$ ) and interactions were analysed by difference from the check using the least significant difference $\left(\mathrm{LSD}_{05}\right)$ values and $95 \%$ or $99 \%$ probability levels marked as $* *$ and $*$ respectively. The relationships between experimental data were investigated using a linear regression analysis with software STAT ENG, version 1.5 (Tarakanovas, Raudonius, 2003).

\section{Results and discussion}

Soil mineral nitrogen (SMN) content. Results of ANOVA showed that the SMN, N-NO and $\mathrm{N}-\mathrm{NH}_{4}$ contents in the soil in spring, before field pea sowing (2014) were significantly influenced by the use of white mustard as a catch crop, utilisation of spring barley straw from the previous year and intensity of barley fertilisation (except for $\mathrm{N}-\mathrm{NH}_{4}$ ) (Table 2).

Interaction of $\mathrm{S} \times \mathrm{F}$ and $\mathrm{CC} \times \mathrm{F}$ has significant effect on the variation of $\mathrm{N}-\mathrm{NO}_{3}$ content, while $\mathrm{CC} \times$ $\mathrm{F}$ interaction had significant influence on the variation of $\mathrm{SMN}$ content. The interaction between $\mathrm{CC} \times \mathrm{S} \times \mathrm{F}$ gave a significant impact on $\mathrm{N}_{-} \mathrm{NH}_{4}$ content $(p=0.035)$. According to the results of ANOVA (2015), catch crop, straw and fertilisation had a significant effect on SMN and $\mathrm{N}-\mathrm{NO}_{3}$. There was no interaction between the factors. The amount of $\mathrm{N}_{-} \mathrm{NH}_{4}$ depended on the incorporated organic matter CC $(p<0.05)$, straw $(p<0.01)$ and interaction of $\mathrm{CC} \times \mathrm{S}(p<0.01)$ and of $\mathrm{CC} \times \mathrm{F}(p<0.05)$. Based on probability (Table 2), data of SMN and its components as factorial interactions or separate factors are presented graphically (Figs 1 and 2). 
Table 2. Probability $(p)$ level of factors for soil mineral nitrogen (SMN) content and its components in the spring of 2014 and 2015

\begin{tabular}{|c|c|c|c|c|c|c|}
\hline \multirow{2}{*}{ Factor / treatment } & \multicolumn{3}{|c|}{2014} & \multicolumn{3}{|c|}{2015} \\
\hline & SMN & $\mathrm{N}-\mathrm{NO}_{3}$ & $\mathrm{~N}-\mathrm{NH}_{4}$ & SMN & $\mathrm{N}-\mathrm{NO}_{3}$ & $\mathrm{~N}-\mathrm{NH}_{4}$ \\
\hline A: Catch crop (CC) & $<0.001 * *$ & $0.001 * *$ & $0.011^{4}$ & $0.007 * *$ & $0.013^{*}$ & $0.022^{*}$ \\
\hline B: Straw management $(\mathrm{S})$ & $0.001 * *$ & $0.005 * *$ & $0.008 * *$ & $<0.001 * *$ & $<0.001 * *$ & $<0.001 * *$ \\
\hline C: Fertilisation $(\mathrm{F})$ & $0.012 *$ & $0.017^{*}$ & 0.184 & $<0.001 * *$ & $<0.001 * *$ & 0.736 \\
\hline $\mathrm{CC} \times \mathrm{S}$ & 0.900 & 0.196 & $0.005 * *$ & 0.184 & 0.094 & $0.001 * *$ \\
\hline $\mathrm{CC} \times \mathrm{F}$ & $0.015 *$ & $0.011 *$ & 0.762 & 0.481 & 0.496 & $0.028 *$ \\
\hline $\mathrm{S} \times \mathrm{F}$ & 0.213 & $0.033 *$ & 0.072 & 0.633 & 0.646 & 0.583 \\
\hline $\mathrm{CC} \times \mathrm{S} \times \mathrm{F}$ & 0.114 & 0.231 & $0.035^{*}$ & 0.155 & 0.125 & 0.141 \\
\hline
\end{tabular}

$\mathrm{N}-\mathrm{NO}_{3}$ - nitrate nitrogen, $\mathrm{N}-\mathrm{NH}_{4}-$ ammonium nitrogen; *, ** - differences significant at $95 \%$ and $99 \%$ probability levels

In 2014, significantly lower content of mineral $\mathrm{N}-\mathrm{NO}_{3}$ and $\mathrm{N}-\mathrm{NH}_{4}$ was found in the soil, where white mustard had been grown (Fig. 1). The use of the previous year spring barley straw $\left(+\mathrm{N}_{30}\right)$ as an organic fertiliser significantly increased the content of SMN by on average $13.8 \%$, compared to the soil without straw. The SMN content increased with increasing mineral fertiliser (especially $\mathrm{N}$ ) rates for barley. A significantly higher SMN and $\mathrm{N}-\mathrm{NO}_{3}$ content (on average $20.9 \%$ and $20.5 \%$, respectively) was found in the soil without white mustard cultivation, where barley received more intensive fertilisation (WCC-IF), compared to the unfertilised (WCC-UF) soil. In the treatment with white mustard, the use of mineral fertilisers reduced the content of SMN and $\mathrm{N}-\mathrm{NO}_{3}$, while applying sustainable fertilising the decrease was significant. However, the factors $\mathrm{S} \times \mathrm{F}$ interaction showed that, where barley straw $\left(+\mathrm{N}_{30}\right)$ had been incorporated in the autumn, $\mathrm{N}-\mathrm{NO}_{3}$ increased in S-UF and S-IF plots (on average $21.2 \%$ and $15.2 \%$, respectively), compared to WS-UF treatments. A significantly higher level (on average $18.2 \%$ ) of $\mathrm{N}-\mathrm{NO}_{3}$ was also found in the intensively fertilised plots without straw. Due to the interaction of $\mathrm{CC} \times \mathrm{S} \times \mathrm{F}$, significantly higher $\mathrm{N}-\mathrm{NH}_{4}$ content was found, when barley had been fertilised intensively and its straw had been used as a fertiliser (WCC-S-IF). The effect of the factors was less consistent in the plots with white mustard.

Technologies used during the post-harvest period of cereals affect soil properties and processes. Shortly after spring barley harvesting, mineral $\mathrm{N}$ fertiliser was applied to induce straw decomposition. In the autumn and during straw decomposition, fertiliser $\mathrm{N}$ and SMN were immobilized by the decomposing microflora (Arlauskiene et al., 2019). Due to the release of immobilized N, in spring, SMN content significantly increased in the soil, where straw had been incorporated.

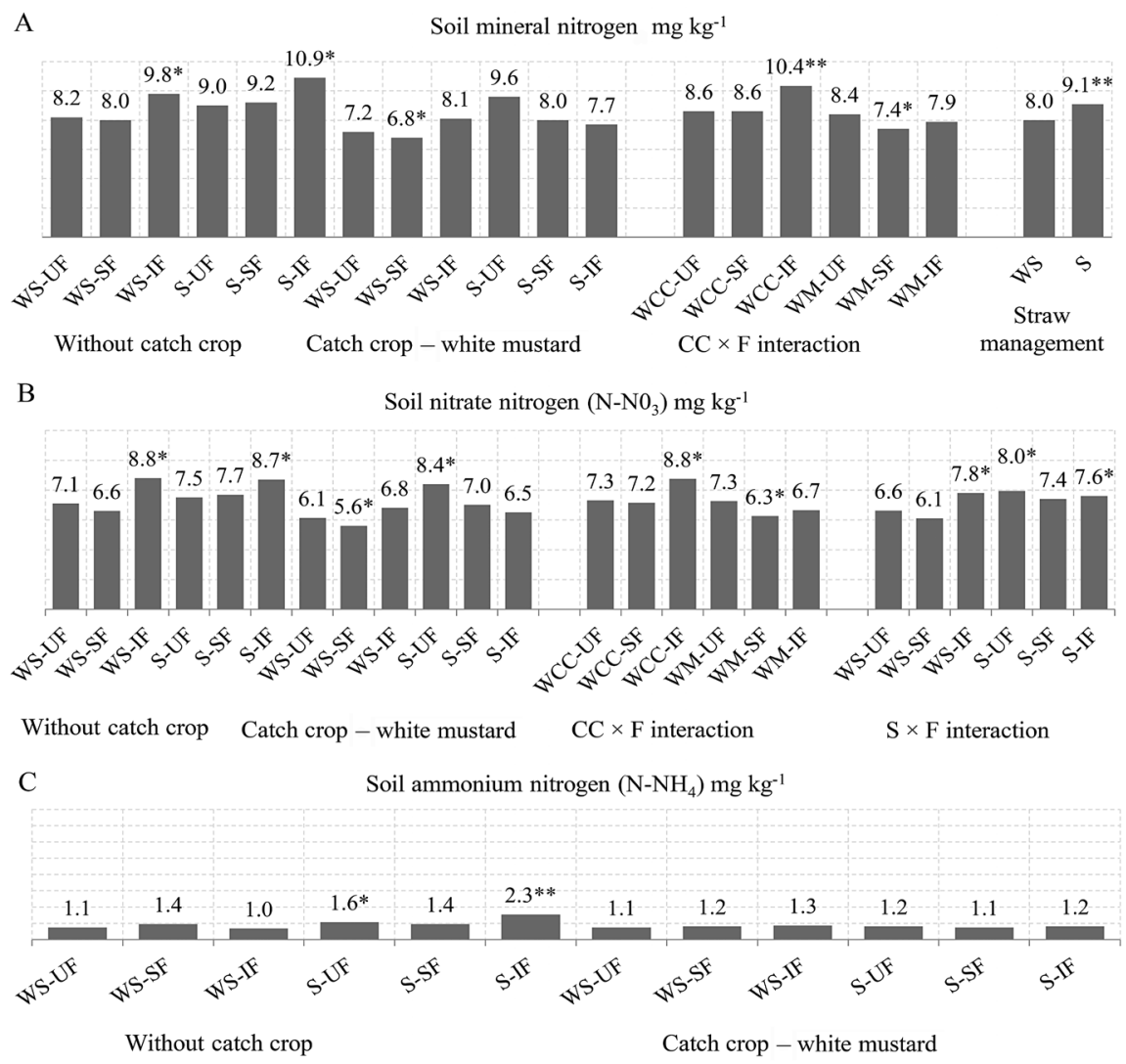

WCC - without catch crop, WM - catch crop - white mustard; WS - straw removed from the field, S - straw chopped and spread; $\mathrm{UF}$ - unfertilised, SF - sustainable fertilising, IF - intensive fertilising; * **- differences significant at $95 \%$ and $99 \%$ probability levels; $\mathrm{LSD}_{05} \mathrm{SMN} \mathrm{B}-0.60, \mathrm{AC}-1.03, \mathrm{ABC}-1.46$; N-NO $3 \mathrm{AC}-0.91, \mathrm{BC}-0.91, \mathrm{ABC}-1.29 ; \mathrm{N}_{3} \mathrm{NH}_{4} \mathrm{ABC}-0.49$

Figure 1. The effect of white mustard catch crop (CC, factor A), spring barley straw management (S, factor B) and mineral fertilisation (F, factor $\mathrm{C}$ ) on the content of soil mineral nitrogen (SMN) and its components in 0-60 cm layer (spring, 2014) 
In addition, the use of straw as a fertiliser helps to tighten the $\mathrm{N}$ cycle (Soon, Lupwayi, 2012), thus reducing nitrate leaching in the autumn. This is done to retain $\mathrm{N}$ in the soil until the start of the next (new) growing season. Temporary $\mathrm{N}$ immobilization in the microbial biomass increases $\mathrm{N}$ accumulation in the soil (Jensen, 1997).

Nitrogen is also needed to grow white mustard. While white mustard plant mass was incorporated in late autumn during ploughing, decomposition of this mass and $\mathrm{N}$ immobilization continued in spring, herewith reducing SMN content in the soil. White mustard matures quickly, which can increase the amount of lignified compounds and the C:N (Justes et al., 2009). This is what occurred during our experiment. The $\mathrm{C}: \mathrm{N}$ value of white mustard aboveground mass varies markedly and depends on the agrotechnological and meteorological conditions (Arlauskienè et al., 2019).

The residual effects of catch crop, spring barley straw and fertilisation were investigated in 2015 (Fig. 2), after the resumption of vegetation of winter wheat, SMN content increased on average from $8.6 \mathrm{mg} \mathrm{kg}^{-1}$ (2014) to $12.6 \mathrm{mg} \mathrm{kg}^{-1}$ (2015). The increase in SMN was determined by the decomposition of the incorporated residues of pea and the release of immobilized $\mathrm{N}$.

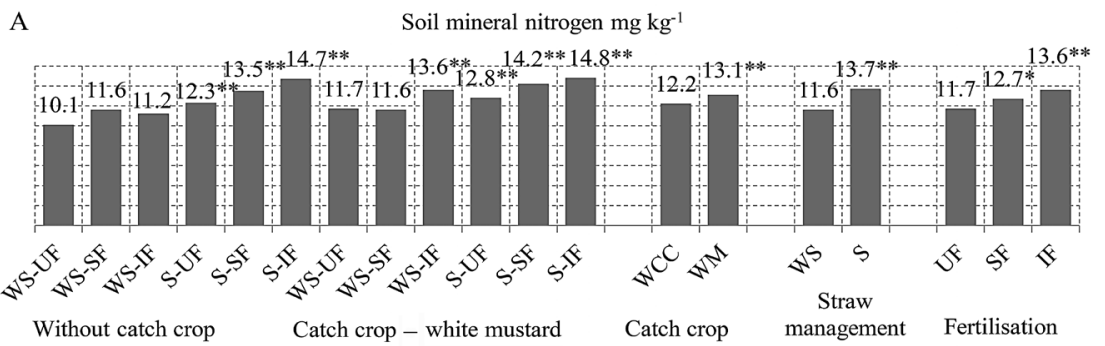

B Soil nitrate nitrogen $\left(\mathrm{N}-\mathrm{NO}_{3}\right) \mathrm{mg} \mathrm{kg}^{-1}$

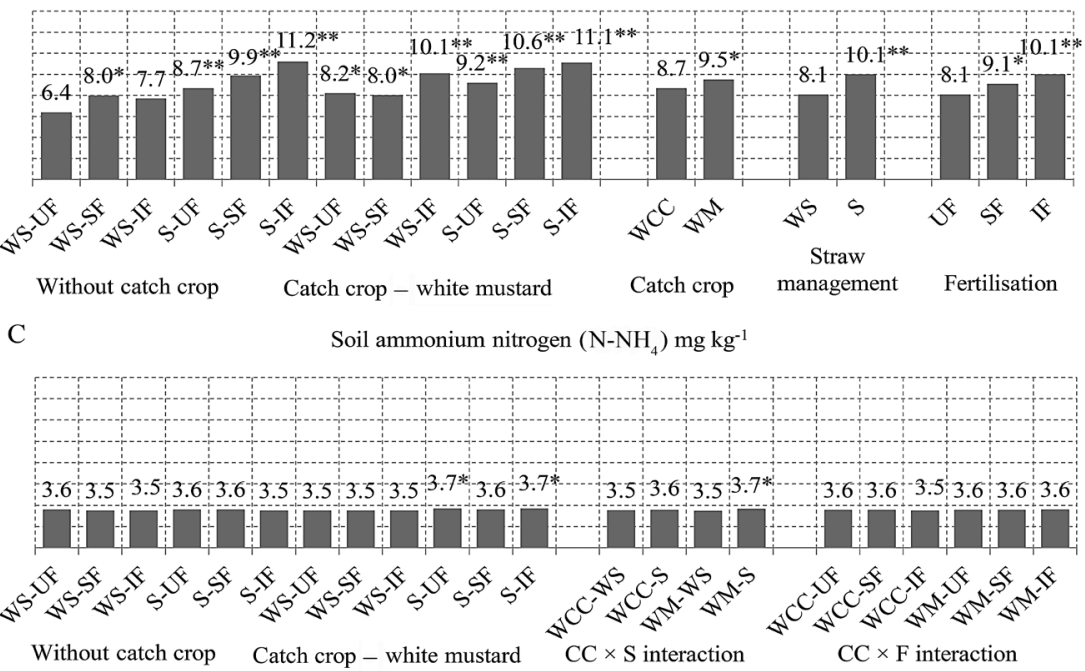

Explanation under Figure 1; $\mathrm{LSD}_{05} \mathrm{SMN} \mathrm{A}-0.63, \mathrm{~B}-0.63, \mathrm{C}-0.77, \mathrm{ABC}-1.55 ; \mathrm{N}-\mathrm{NO} \mathrm{A}_{3} \mathrm{~A}-0.64, \mathrm{~B}-0.64, \mathrm{C}-0.79, \mathrm{ABC}-1.57$; $\mathrm{N}-\mathrm{NH}_{4} \mathrm{AB}-0.07, \mathrm{AC}-0.08, \mathrm{ABC}-0.12$

Figure 2. The effect of white mustard catch crop (CC, factor A), spring barley straw management (S, factor B) and mineral fertilisation (F, factor $\mathrm{C}$ ) on the content of soil mineral nitrogen (SMN) and its components in 0-60 cm soil layer (spring, 2015)

In the second experimental year, the catch crop white mustard significantly increased SMN content - on average by $7.4 \%$, straw (barley and peas) use as manure - on average by $18.1 \%$ and fertilisation: $\mathrm{SF}-8.5 \%$, IF $-16.2 \%$ on average, compared to the treatments without catch crop, with removed straw and unfertilised soil, respectively. The content of $\mathrm{N}-\mathrm{NO}_{3}$ varied in a similar way. The $\mathrm{N}_{-} \mathrm{NH}_{4}$, which is less mobile, compared to $\mathrm{N}-\mathrm{NO}_{3}$, accounted for $28.6 \%$ (average data) of total SMN. Significantly higher (on average $5.7 \%$ ) $\mathrm{N}^{-\mathrm{NH}_{4}}$ content was found in the plots, where catch crop white mustard and straw were incorporated together, compared to the soil WCC-WS. It can be argued that remineralization of immobilized $\mathrm{N}$ took place. A negative effect of intensive fertilising on $\mathrm{N}^{-\mathrm{NH}_{4}}$ was detected in the treatment without catch crop $(\mathrm{C} C \times \mathrm{F}$ interaction $)$.

Field pea productivity. The results of ANOVA are presented in Table 3 . Catch crop caused the differences between pod number and grain number per plot, TGW, straw and grain yield, grain crude protein and $\mathrm{K}$ content.
Straw application had a significant effect on all studied parameters. Interaction of $\mathrm{CC} \times \mathrm{S}$ caused the differences in grain $\mathrm{K}$ content $(p=0.040)$.

Formation of field pea productivity. Cultivation of white mustard as a preceding crop for peas increased the number of pea pods by $13.7 \%$ and the number of grains on average by $18.2 \%$, compared to the plots without catch crop (Table 4). In contrast, the use of spring barley straw as a fertiliser decreased the number of pods and the number of grains on average by $18.7 \%$ and $22.5 \%$, respectively, compared to the plots, where straw had not been used. The highest number of pods was formed, when peas were grown after the catch crop without using straw as a fertiliser (regardless of fertilisation intensity). In this case, the plants produced the highest number of grains. The TGW of pea was high and ranged from 291.8 to $316.8 \mathrm{~g}$, analogous with the number of pods and the number of grains per plot. A strong, significant negative correlation was found between SMN and the number of pods, number of 
Table 3. Probability $(p)$ level of factors for field pea yield components, yield and grain chemical composition

\begin{tabular}{|c|c|c|c|c|c|c|c|c|}
\hline \multirow[b]{2}{*}{ Factor / treatment } & \multirow[b]{2}{*}{ Pod number } & \multirow{2}{*}{$\begin{array}{l}\text { Grain } \\
\text { number }\end{array}$} & \multirow[b]{2}{*}{ TGW } & \multicolumn{2}{|c|}{ Yield } & \multicolumn{3}{|c|}{ Grain chemical composition } \\
\hline & & & & straw & grain & $\begin{array}{l}\text { crude } \\
\text { protein }\end{array}$ & $\begin{array}{c}\mathrm{P} \\
\text { content }\end{array}$ & $\begin{array}{c}\mathrm{K} \\
\text { content }\end{array}$ \\
\hline$\overline{\mathrm{A}: \text { Catch crop (CC) }}$ & $0.006^{* *}$ & $<0.001 * *$ & $0.041^{*}$ & $0.014 *$ & $0.005 * *$ & $0.001 * *$ & 0.110 & $0.040^{*}$ \\
\hline B: Straw management (S) & $<0.001 * *$ & $<0.001 * *$ & $<0.001 * *$ & $<0.001 * *$ & $<0.001 * *$ & $<0.001 * *$ & $0.001 * *$ & $0.045^{*}$ \\
\hline C: Fertilisation $(\mathrm{F})$ & 0.282 & 0.236 & 0.434 & 0.413 & 0.118 & 0.094 & 0.688 & 0.553 \\
\hline $\mathrm{CC} \times \mathrm{S}$ & 0.804 & 0.528 & 0.656 & 0.783 & 0.157 & 0.673 & 0.306 & $0.040^{*}$ \\
\hline $\mathrm{CC} \times \mathrm{F}$ & 0.133 & 0.089 & 0.939 & 0.811 & 0.822 & 0.931 & 0.827 & 0.749 \\
\hline $\mathrm{S} \times \mathrm{F}$ & 0.914 & 0.988 & 0.189 & 0.899 & 0.482 & 0.749 & 0.640 & 0.962 \\
\hline $\mathrm{CC} \times \mathrm{S} \times \mathrm{F}$ & 0.897 & 0.736 & 0.998 & 0.691 & 0.763 & 0.584 & 0.246 & 0.518 \\
\hline
\end{tabular}

TGW - thousand grain weight; * ** - differences significant at $95 \%$ and $99 \%$ probability levels

Table 4. The effect of white mustard catch crop, spring barley straw management and mineral fertilisation on the variation of field pea yield components yield and grain chemical composition

\begin{tabular}{|c|c|c|c|c|c|c|c|c|c|c|}
\hline \multicolumn{3}{|c|}{ Treatment / factor } & \multirow{3}{*}{$\begin{array}{c}\text { Pod } \\
\text { number } \\
\text { pod } \mathrm{m}^{-2}\end{array}$} & \multirow{3}{*}{$\begin{array}{l}\text { Grain } \\
\text { number } \\
\text { grain } \mathrm{m}^{-2}\end{array}$} & \multirow{3}{*}{$\begin{array}{c}\text { TGW } \\
\mathrm{g}\end{array}$} & \multicolumn{2}{|c|}{ Yield } & \multicolumn{3}{|c|}{ Grain chemical composition } \\
\hline \multirow{2}{*}{$\begin{array}{l}\text { catch } \\
\text { crop } \\
\text { (A) }\end{array}$} & \multirow{2}{*}{$\begin{array}{c}\text { straw } \\
\text { management } \\
\text { (B) }\end{array}$} & \multirow{2}{*}{$\begin{array}{l}\text { fertilisation } \\
\text { (C) }\end{array}$} & & & & grain & straw & $\begin{array}{c}\text { crude } \\
\text { protein }\end{array}$ & $\begin{array}{c}\mathrm{P} \\
\text { content }\end{array}$ & $\begin{array}{c}\mathrm{K} \\
\text { content }\end{array}$ \\
\hline & & & & & & \multicolumn{2}{|c|}{$\mathrm{kg} \mathrm{ha}^{-1}$} & \multicolumn{3}{|c|}{$\mathrm{g} \mathrm{kg}^{-1} \mathrm{DM}$} \\
\hline \multirow[t]{6}{*}{ WCC } & WS & UF & 490 & 1702 & 309.0 & 4899 & 3635 & 180 & 5.24 & 19.1 \\
\hline & & SF & 476 & 1707 & 305.1 & 5021 & 3876 & 177 & 5.33 & 19.2 \\
\hline & & IF & 404 & 1396 & 304.1 & 5003 & 3770 & 191 & 5.18 & 18.8 \\
\hline & $\mathrm{S}$ & UF & $382 * *$ & $1352 * *$ & $291.8 *$ & $3917 * *$ & 3132 & $151 * *$ & 4.81 & 19.0 \\
\hline & & SF & $386 * *$ & $1286 * *$ & 297.5 & $4225 * *$ & 3192 & $155 * *$ & $4.71 *$ & 19.1 \\
\hline & & IF & $318 * *$ & $1108 * *$ & $292.4 *$ & $4026 * *$ & 3154 & $160 *$ & 4.91 & 19.1 \\
\hline \multirow[t]{6}{*}{ WM } & WS & UF & 513 & 1820 & 316.8 & 5071 & 4037 & 198 & 5.42 & 19.1 \\
\hline & & $\mathrm{SF}$ & 487 & 1930 & 310.7 & 5147 & 4115 & 198 & 5.10 & 18.9 \\
\hline & & IF & 523 & 1959 & 309.8 & 5148 & $4339 *$ & $200 *$ & 5.39 & 19.0 \\
\hline & $\mathrm{S}$ & UF & 427 & 1407 & 296.9 & $4185 * *$ & 3234 & $162 *$ & 4.92 & 18.5 \\
\hline & & SF & 420 & 1539 & 302.4 & 4644 & 3688 & 166 & 5.10 & 18.3 \\
\hline & & IF & 421 & 1451 & $296.0^{*}$ & 4613 & 3533 & 176 & 5.13 & $17.8^{*}$ \\
\hline \multicolumn{11}{|c|}{ Mean of factors } \\
\hline WCC & & & 409 & 1425 & 300.0 & 4515 & 3460 & 169 & 5.03 & 19.1 \\
\hline WM & & & $465 * *$ & $1684 * *$ & $305.4 *$ & $4801 * *$ & $3824^{*}$ & $183 * *$ & 5.18 & $18.6^{*}$ \\
\hline & & & 482 & 1752 & 309.3 & 5048 & 3962 & 191 & 5.28 & 19.0 \\
\hline & $\mathrm{S}$ & & $392 * *$ & $1357 * *$ & $296.2 *$ & $4268 * *$ & $3322 * *$ & $162 * *$ & $4.93 * *$ & $18.6^{*}$ \\
\hline & & UF & 453 & 1570 & 303.6 & 4518 & 3510 & 173 & 5.10 & 18.9 \\
\hline & & $\mathrm{SF}$ & 442 & 1616 & 303.9 & $4759 *$ & 3718 & 174 & 5.06 & 18.9 \\
\hline & & IF & $417^{*}$ & 1479 & 300.6 & 4698 & 3699 & $182^{*}$ & 5.15 & 18.7 \\
\hline
\end{tabular}

Explanation under Figure 1; TGW - thousand grain weight; DM - dry matter; LSD pod number A - 38.6, B - 38.6, C - 47.3, $\mathrm{ABC}$ - 94.5; grain number $\mathrm{A}-134, \mathrm{~B}-134, \mathrm{C}-164, \mathrm{ABC}-327$; TGW A - 5.00, B - 5.00, C - 6.12, ABC - 12.24; grain yield $\mathrm{A}-195, \mathrm{~B}-195, \mathrm{C}-238, \mathrm{ABC}-477$; straw yield A - 284, B - 284, C - 348, ABC - 697; crude protein A - 7.3, B - 7.3, C - 8.9, $\mathrm{ABC}-17.8$; P content $\mathrm{A}-0.182, \mathrm{~B}-0.182, \mathrm{C}-0.223$, ABC -0.447 ; K content $\mathrm{A}-0.41, \mathrm{~B}-0.41, \mathrm{C}-0.50, \mathrm{ABC}-1.00$

grains per plot and TGW $(r=-0.79, p<0.01, r=-0.84$, $p<0.01$ and $r=-0.69, p<0.05$, respectively). Similarly, the relationship between $\mathrm{N}-\mathrm{NO}_{3}$ and the said biometric parameters varied. These relationships indicated that the increase in SMN and $\mathrm{N}-\mathrm{NO}_{3}$ content determined weaker formation of pea yield components.

Field pea grain and straw yield. According to the average data, white mustard cultivation pea yield increased by $286 \mathrm{~kg} \mathrm{ha}^{-1}$, or $6.3 \%$, compared to the plots without catch crop (Table 4). The use of straw for fertilisation pea grain yield significantly reduced on average by $780 \mathrm{~kg} \mathrm{ha}^{-1}$, or $15.5 \%$, compared to the plots, where spring barley straw had been removed from the field. White mustard mitigated the negative effect of straw. The influence of fertilisation intensity on pea grain yield was not significant. Pea straw yield varied similarly to grain yield. There was a strong inverse correlation $(r=-0.68, p<0.05)$ between pea grain yield and SMN in the spring. The components of yield structure (plant density, number of pods and grains, TGW, etc.) depend on local conditions, agricultural practices and have varied influence on the yield of different species of legumes (Živanov et al., 2018). The current experiment showed a strong linear relationship between the yield of pea and number of pods, number of grains per $\mathrm{m}^{2}$ and TGW ( $r=0.83,0.83$ and 0.90 , respectively, $p<0.01)$

Most $\mathrm{N}$ accumulated in pea yield $(65-75 \%)$ derived from biological $\mathrm{N}$ fixation (Jensen, 1997). SMN has a significant influence on legume crop nutrition only in the early stages of development until $\mathrm{N}_{2}$ fixation from the air has begun. There is a lot of discussion about the negative influence of SMN and mineral $\mathrm{N}$ fertilisers on biological $\mathrm{N}$ fixation. The $\mathrm{N}_{2}$ fixation and yield of legumes depend on plant genotype, the $\mathrm{N}$-form $\left(\mathrm{N}-\mathrm{NO}_{3}\right.$ or $\left.\mathrm{N}-\mathrm{NH}_{4}\right)$ used (Cooper, Scherer, 2012) and other agrotechnological measures. The studies with organic fertilisers (wide $\mathrm{C}: \mathrm{N}$ ) showed that the yield of pea increased, in contrast to oats (Jannoura et al., 2014). Plants and their residues can release a number of secondary metabolites into the rhizosphere. The latter have huge influence on soil activities, i.e. the availability of nutrients, plant mineral nutrition, essential nutrient cycles, and soil enzyme, bacteria and macrofauna activities (Cesco et al., 2012). All of this can indirectly affect $\mathrm{N}$ mineralisation and immobilization processes in the soil (Cooper, Scherer, 2012). Fuchs et al. (2014) found that depressions of legume yield in organic arable farming have mainly biotic causes.

Field pea grain chemical composition. The crude protein content of pea grain in this study varied from 151 to $200 \mathrm{~g} \mathrm{~kg}^{-1} \mathrm{DM}$ (Table 4). Due to the mineralisation process, the spring barley straw spread markedly $(15.2 \%)$ reduced the accumulation of $\mathrm{N}$ compounds. On the other hand, cultivation of the shortterm catch crop (white mustard) following the barley harvest significantly increased crude protein content of pea grain from about $7.5 \%$ to $8 \%$, irrespective of the straw management. Overall, the highest crude protein 
content reported in the experiment occurred in the peas, when white mustard had been used and barley straw had been removed from the field. The intensive PK fertilisation rates showed a tendency to increase (4.4$4.9 \%$ ) crude protein content of pea grain, compared to unfertilised and sustainable fertilisation plots, but the differences were significant at levels less than $95 \%$ of probability. These results of grain crude protein accumulation essentially corroborated the previously described influence of factors on the pea grain yield.

Compared to the results of other researchers, not always consistent effect of white mustard incorporation was observed on the succeeding crop yield. According to Balnyte et al. (2009), white mustard sown after the main crop and used as a catch crop for green manure in organic agriculture had no positive effect on the yield of cereals. Thorup-Kristensen (1994) carried out a study with 10 widely different plant species (one of them was white mustard) comparing their ability to reduce SMN levels in the autumn and to improve the $\mathrm{N}$ nutrition of the succeeding crop. The effect of the catch crop on $\mathrm{N}$ uptake by the succeeding barley crop was positive and varied from 13 to $66 \mathrm{~kg} \mathrm{ha}^{-1} \mathrm{~N}$. It has been documented that straw microbial $\mathrm{N}$ immobilization and $\mathrm{N}$ losses could leave limited amounts of available $\mathrm{N}$ for uptake by the subsequent crops (Hauggaard-Nielsen et al., 2009). Based on the research by Jensen (1991), where barley and pea straw incorporation in the soil reduced $\mathrm{N}$ accumulation in the aftersown white mustard, it can be supposed that reduced $\mathrm{N}$ accumulation of mustard can have negative effect on the grain quality of the postcrop.

The effect of the applied measures (white mustard and barley straw) on the accumulation of $\mathrm{P}$ and $\mathrm{K}$ content of pea grain was not as pronounced as on crude protein content (Table 4). Pea grain accumulated less $\mathrm{P}$, when the straw from the preceding crop (barley) had been incorporated into the soil. Without straw, the average $P$ content in pea grain was $5.28 \mathrm{~g} \mathrm{~kg}^{-1} \mathrm{DM}$, while with straw $\mathrm{P}$ content decreased by $0.35 \mathrm{~g} \mathrm{~kg}^{-1} \mathrm{DM}$, or $6.6 \%$. The $\mathrm{K}$ content determined in pea grain ranged from 17.8 to $19.2 \mathrm{~g} \mathrm{~kg}^{-1} \mathrm{DM}$. A complex application of measures, when the straw was left after barley cultivation and white mustard was sown, reduced $\mathrm{K}$ content of pea grain by up to $2.1 \%$. Fertiliser application did not have any significant effect on PK content of pea grains.

Winter wheat productivity. ANOVA results showed that the formation of winter wheat yield components was mainly influenced by mineral (mostly $\mathrm{N}$ ) fertilisers (Table 5). Fertilisation significantly determined the number of spikes and the number of grains per spike. The nutrients from the straw were released by gradual decomposition of the straw (of barley and peas); therefore, a major influence of the straw was exerted on the yield components that formed later, i.e. the number of grains per spike and the TGW.

Table 5. Probability $(p)$ level of factors for winter wheat yield components, yield and grain chemical composition

\begin{tabular}{|c|c|c|c|c|c|c|c|c|}
\hline \multirow{2}{*}{ Factor / treatment } & \multirow{2}{*}{$\begin{array}{l}\text { Number } \\
\text { of spikes }\end{array}$} & \multirow{2}{*}{$\begin{array}{l}\text { Number } \\
\text { of grains } \\
\text { per spike }\end{array}$} & \multirow{2}{*}{ TGW } & \multicolumn{2}{|c|}{ Yield } & \multicolumn{3}{|c|}{ Grain chemical composition } \\
\hline & & & & straw & grain & crude protein & P content & $\mathrm{K}$ content \\
\hline A: Catch crop (CC) & 0.744 & 0.064 & 0.919 & 0.679 & $<0.001 * *$ & 0.239 & $0.002 * *$ & $<0.001 * *$ \\
\hline B: Straw management $(\mathrm{S})$ & 0.603 & $0.032 *$ & $0.002 * *$ & 0.945 & $0.028 *$ & $0.022 *$ & $0.003 * *$ & $<0.001 * *$ \\
\hline C: Fertilisation $(\mathrm{F})$ & $<0.001 * *$ & $0.029 *$ & 0.428 & $<0.001 * *$ & $<0.001 * *$ & $<0.001 * *$ & $0.012 *$ & $<0.001 * *$ \\
\hline $\mathrm{CC} \times \mathrm{S}$ & 0.158 & 0.184 & 0.183 & 0.631 & 0.392 & 0.229 & 0.863 & 0.818 \\
\hline $\mathrm{CC} \times \mathrm{F}$ & 0.873 & 0.305 & 0.372 & 0.923 & 0.709 & 0.083 & 0.194 & 0.261 \\
\hline $\mathrm{S} \times \mathrm{F}$ & 0.685 & 0.660 & 0.364 & 0.745 & 0.165 & 0.227 & $0.011 *$ & 0.736 \\
\hline $\mathrm{CC} \times \mathrm{S} \times \mathrm{F}$ & 0.097 & 0.997 & 0.811 & 0.598 & 0.610 & 0.796 & 0.487 & $0.029 *$ \\
\hline
\end{tabular}

TGW - thousand grain weight; * ** - differences significant at $95 \%$ and $99 \%$ probability levels

The grain yield was significantly influenced by all investigated factors: catch crop cultivation $(p<0.001)$, mineral fertilisation $(p<0.001)$ and straw application as fertiliser $(p=0.028)$; there was no relationship between the factors. The straw yield was determined by mineral fertilisers $(p<0.001)$. The crude protein content accumulated in grain was significantly dependent on the $\mathrm{N}$ supply, i.e. mineral fertilisation $(p<0.001)$ and straw application $(p=0.022)$. The contents of $\mathrm{P}$ and $\mathrm{K}$ in grain were significantly influenced by all investigated factors, their relationship (on $\mathrm{K}$ content) and the relationship between straw and fertilisation (on P content).

Formation of winter wheat productivity. Wheat yield is the result of the number of grains per unit area and the thousand grain weight achieved by these grains (Li et al., 2016; Terille et al., 2017). In our study, mineral fertilisation significantly increased the number of spikes: SF - by $41.3 \%$ and IF - by $47.5 \%$ on average, compared to zero fertilisation (Table 6). There were no significant differences between the mentioned fertilisation treatments. This could be a response to high SMN levels through a variety of measures and winter wheat cultivation after peas.

Adequate $\mathrm{N}$ supply and optimal soil and environmental conditions in the early stages of plant development allowed the use of space to maximize spike formation. The number of grains per spike was increased (on average $3.1 \%$ ) by straw retention. Grain formation covers most of the wheat growing season and is dependent on the formation and development of spikelets and flower buds as well as on pollination (Terrile et al., 2017), the amount of accumulated assimilates and their supply for grain filling at the end of crop growing season (Li et al., 2016; Yan et al., 2019).

Therefore, a constant supply of nutrients using straw, additional fertilisation with $\mathrm{N}$ fertiliser during the cereal growing season facilitated the formation of the number of grains per spike (40.9-44.6). In the current study, intensive fertilisation tended to reduce the number of grains per spike (on average 1.7\%), compared to zero fertilisation. It can be stated that due to high number of spikes per unit area, there was grain competition for assimilation products, which became a limiting factor. High tillering energy may have caused the competition between productive tillers, resulting in a low TGW (37.7-39.1 g). The TGW was increased on average by $1.6 \%$ only by the use of straw for fertiliser, compared to zero fertilisation. Yield productivity indicators that form at the end of ear development (as a TGW) cannot be compensated for by other productivity indicators; therefore, their negative change has a significant effect on plant productivity (Terrile et al., 2017). Fertiliser had extremely significant effects on the time of appearance of maximum filling rate and the final TGW (Yan et al., 2019).

Winter wheat grain yield. The winter wheat grown after peas (without mineral fertilisers, straw and catch crop) produced a yield of $4964 \mathrm{~kg} \mathrm{ha}^{-1}$ (Table 6). The highest yield increase was obtained with mineral 
Table 6. The effect of white mustard catch crop, spring barley straw management and mineral fertilisation on the variation of winter wheat yield components, yield and grain chemical composition

\begin{tabular}{|c|c|c|c|c|c|c|c|c|c|c|}
\hline \multicolumn{3}{|c|}{ Treatment / factor } & \multirow{3}{*}{$\begin{array}{l}\text { Number } \\
\text { of spikes } \\
\text { spike } \mathrm{m}^{-2}\end{array}$} & \multirow{3}{*}{$\begin{array}{l}\text { Number } \\
\text { of grains } \\
\text { per spike }\end{array}$} & \multirow{3}{*}{$\begin{array}{c}\text { TGW } \\
\mathrm{g}\end{array}$} & \multicolumn{2}{|c|}{ Yield } & \multicolumn{3}{|c|}{ Grain chemical composition } \\
\hline \multirow{2}{*}{$\begin{array}{l}\text { catch } \\
\text { crop } \\
\text { (A) }\end{array}$} & \multirow{2}{*}{$\begin{array}{c}\text { straw } \\
\text { management } \\
\text { (B) }\end{array}$} & \multirow{2}{*}{$\begin{array}{l}\text { fertilisation } \\
\text { (C) }\end{array}$} & & & & grain & straw & $\begin{array}{l}\text { crude } \\
\text { protein }\end{array}$ & $\begin{array}{c}\mathrm{P} \\
\text { content }\end{array}$ & $\begin{array}{c}\mathrm{K} \\
\text { content }\end{array}$ \\
\hline & & & & & & \multicolumn{2}{|c|}{$\mathrm{kg} \mathrm{ha}^{-1}$} & \multicolumn{3}{|c|}{$\mathrm{g} \mathrm{kg}^{-1} \mathrm{DM}$} \\
\hline \multirow[t]{5}{*}{ WCC } & WS & $\begin{array}{l}\text { UF } \\
\text { SF }\end{array}$ & $\begin{array}{c}489 \\
725^{* * *}\end{array}$ & $\begin{array}{l}42.0 \\
42.4\end{array}$ & $\begin{array}{l}38.3 \\
38.1\end{array}$ & $\begin{array}{c}4964 \\
7380^{* *}\end{array}$ & $\begin{array}{r}4762 \\
7091 * *\end{array}$ & $\begin{array}{r}87 \\
113^{* * *}\end{array}$ & $\begin{array}{l}3.46 \\
3.46\end{array}$ & $\begin{array}{l}4.63 \\
4.50\end{array}$ \\
\hline & & IF & $723 * *$ & 41.2 & 38.2 & $7941 * *$ & $7759 * *$ & $128 * *$ & 3.36 & $4.35^{*}$ \\
\hline & $\mathrm{S}$ & UF & 493 & 44.6 & 38.3 & 4624 & 4655 & 88 & 3.50 & $4.30 * *$ \\
\hline & & $\mathrm{SF}$ & $638 * *$ & 44.4 & 39.0 & $7491 * *$ & $7342 * *$ & $124 * *$ & $3.21 * *$ & 4.42 \\
\hline & & IF & $712 * *$ & 42.6 & 38.5 & $7828^{* *}$ & $7807 * *$ & $133 * *$ & $3.30^{*}$ & $4.18^{* *}$ \\
\hline \multirow[t]{5}{*}{ WM } & WS & $\begin{array}{l}\text { UF } \\
\text { SF }\end{array}$ & $\begin{array}{c}495 \\
663 * *\end{array}$ & 40.5 & 37.7 & $\begin{array}{c}5 \overline{2} 58 \\
7930 * *\end{array}$ & $\begin{array}{c}4767 \\
7343 * *\end{array}$ & $\begin{array}{l}95 \\
115 * *\end{array}$ & 3.51 & $\begin{array}{c}4.38^{*} \\
442\end{array}$ \\
\hline & & IF & $693 * *$ & 41.1 & 38.4 & $8277 * *$ & $7815^{* *}$ & $129 * *$ & 3.51 & $4.09^{* *}$ \\
\hline & $\mathrm{S}$ & UF & 458 & 41.6 & 38.6 & 4792 & 465 & 95 & 3.51 & $4.39^{*}$ \\
\hline & & $\mathrm{SF}$ & $711 * *$ & 43.6 & 38.9 & $7701 * *$ & $7155^{* *}$ & $120 * *$ & 3.41 & $4.03 * *$ \\
\hline & & IF & $726^{* *}$ & 40.9 & 39.1 & $8256 * *$ & $7973 * *$ & $131 * *$ & 3.37 & $3.94 * *$ \\
\hline \multicolumn{11}{|c|}{ Mean of factors } \\
\hline \multirow{7}{*}{$\begin{array}{l}\text { WCC } \\
\text { WM }\end{array}$} & & & 630 & 42.9 & 38.4 & 6705 & 6569 & 112 & 3.38 & 4.40 \\
\hline & & & 624 & 41.8 & 38.4 & $7036^{* *}$ & 6618 & 114 & $3.46^{* *}$ & $4.21 * *$ \\
\hline & WS & & 631 & 41.7 & 38.1 & 6958 & 6590 & 111 & 3.46 & 4.40 \\
\hline & $\mathrm{S}$ & & 623 & $43.0^{*}$ & $38.7 * *$ & $6782 *$ & 6598 & $115^{*}$ & $3.38^{* *}$ & $4.21^{* *}$ \\
\hline & & UF & 484 & 42.2 & 38.2 & 4910 & 4709 & 91 & 3.50 & 4.43 \\
\hline & & SF & $684 * *$ & 43 & 38.4 & $7626 * *$ & 723 & $118^{* *}$ & $3.36^{*}$ & 4.34 \\
\hline & & IF & $714 * *$ & 41.5 & 38.6 & $8076^{* *}$ & $7839^{* *}$ & $130 * *$ & $3.39^{* *}$ & $4.14^{* *}$ \\
\hline
\end{tabular}

Explanation under Figure 1; TGW - thousand grain weight, DM - dry matter; LSD number of spikes A - 32.8, B - 32.8, C - 40.1, $\mathrm{ABC}-80.2$; number of grains per spike $\mathrm{A}-1.15, \mathrm{~B}-1.15, \mathrm{C}-1.41, \mathrm{ABC}-2.82$; TGW A $-0.41, \mathrm{~B}-0.41, \mathrm{C}-0.50, \mathrm{ABC}-$ 0.99; grain yield $\mathrm{A}-162, \mathrm{~B}-162, \mathrm{C}-199, \mathrm{ABC}-397$; straw yield $\mathrm{A}-235, \mathrm{~B}-235, \mathrm{C}-288, \mathrm{ABC}-576$; crude protein $\mathrm{A}-3.4$, $\mathrm{B}-3.4, \mathrm{C}-4.1, \mathrm{ABC}-8.3$; $\mathrm{P}$ content $\mathrm{A}-0.059, \mathrm{~B}-0.059, \mathrm{C}-0.073, \mathrm{ABC}-0.146 ; \mathrm{K}$ content $\mathrm{A}-0.094, \mathrm{~B}-0.094, \mathrm{C}-0.115$, $\mathrm{ABC}-0.230$

fertilisers: sustainable fertilisation increased grain yield on average by $55.3 \%$, and intensive fertilisation increased it on average by $64.5 \%$, compared to zero fertilisation. Lower $\mathrm{N}$ fertiliser rates $(\mathrm{SF})$ were more effective than higher ones (IF), with $1 \mathrm{~kg} \mathrm{ha}^{-1} \mathrm{~N}$ mineral fertiliser yielding 26.1 and $21.8 \mathrm{~kg} \mathrm{ha}^{-1}$ grain increase, respectively. The efficiency of mineral fertilisers was higher, where straw as fertiliser was added - the mass of catch crop for organic matter decomposition due to the balanced $\mathrm{N}$ content (Arlauskiene et al., 2019). Cultivation of white mustard as a catch crop increased winter wheat productivity on average by $4.9 \%$, compared to the wheat grown without the catch crop. However, the application of straw as a fertiliser (residual effect of spring barley straw and pea straw) significantly reduced it on average by $2.5 \%$, compared to the treatment, where the straw had been removed from the field. During straw decomposition, some $\mathrm{N}$ amount was immobilized by microorganisms. Therefore, due to remineralization, $\mathrm{N}$ was supplied continuously. Strong grain yield relationships with number of spikes $(r=0.96, p<0.01)$ were established. The grain yield and number of spikes of winter wheat correlated positively and moderately strongly $(r=0.49, p<0.05$ and $r=0.46, p<0.05)$ with the SMN. Abid et al. (2016) found that the plants under higher $\mathrm{N}$ showed delayed senescence, increased grain filling duration and lower grain yield reductions.

Winter wheat grain chemical composition. The variation of winter wheat grain quality depends on fertilisation levels, and fertilisation intensity typically tends to consistently increase grain crude protein content but decrease the amount of grain PK. According to the crude protein content, winter wheat grain varied from fodder type $\left(91 \mathrm{~g} \mathrm{~kg}^{-1}\right)$ in unfertilised plots to high quality $\left(130 \mathrm{~g} \mathrm{~kg}^{-1}\right)$ in intensive fertilisation plots. The amounts of $\mathrm{P}$ and $\mathrm{K}$ in grains of intensive fertilisation treatment, compared to unfertilised treatment decreased by on average 0.11 and $0.29 \mathrm{~g} \mathrm{~kg}^{-1}$, respectively. Straw retention had positive significant effect on grain crude protein accumulation. A particularly notable straw influence was detected in sustainable fertilisation treatments. Straw and catch crop had the same negative effect on grain $\mathrm{K}$ content, but grain $\mathrm{P}$ content was affected differently - significantly decreased in straw retention treatments but increased in white mustard treatments.

\section{Conclusions}

1. Spreading of spring barley straw $\left(+\mathrm{N}_{30}\right)$ after harvest had significant influence on soil mineral nitrogen $(\mathrm{SMN})$ and nitrate nitrogen $\left(\mathrm{N}-\mathrm{NO}_{3}\right)$ content in the spring; the increase averaged $13.8 \%$ and $11.8 \%$, respectively. The cultivation of white mustard as a catch crop resulted in decreasing SMN content. There was found negative significant effect of the relationship between catch crop and fertilisation on $\mathrm{N}-\mathrm{NO}_{3}$ content in the soil. However, the relationship between straw and fertilisation positively influenced $\mathrm{N}_{-} \mathrm{NO}_{3}$ content. Ammonium nitrogen (N$\mathrm{NH}_{4}$ ) accounted for a small proportion of mineral $\mathrm{N}$, and its content increased significantly with the use of straw as a fertiliser and intensive fertilisation without catch crop cultivation. During the second year of the effect of the applied measures, SMN content was significantly increased by the incorporation of straw (18.1\%) and white mustard mass $(7.4 \%)$ and application of mineral fertilisers, mainly composed of $\mathrm{N}$ : sustainable fertilising (SF) $-8.5 \%$ and intensive fertilising (IF) $-16.2 \%$ on average.

2. The decrease in $\mathrm{SMN}$ and $\mathrm{N}-\mathrm{NO}_{3}$ had positive impact on the formation of field pea biometric indicators and grain yield. The highest pea grain yield was obtained in the treatments, where white mustard biomass had been incorporated; the yield increased by $6.3 \%$ (or $286 \mathrm{~kg} \mathrm{ha}^{-1}$ ), compared to the pea crop cultivated without a catch crop. The spreading of barley straw $\left(+\mathrm{N}_{30}\right)$ markedly reduced the grain yield of peas $(15.5 \%)$. A strong positive linear correlation was found between pea grain yield and the number of pea pods, number of grains per $\mathrm{m}^{2}$ and thousand grain weight (TGW).

3. The PK fertilisation was less effective on pea grain crude protein accumulation than catch crop. Due to white mustard cultivation, the crude protein content of pea grains increased on average by $13-16 \mathrm{~g} \mathrm{~kg}^{-1} \mathrm{DM}$ $(7.5-8.0 \%)$. The highest crude protein content in the pea grain was recorded when white mustard had been grown as a catch crop and barley straw had been removed from 
the field. Pea grain quality improvement with barley straw spreading was ineffective due to the straw mineralisation process, crude protein content in pea grains significantly decreased $(15.2 \%)$ and there was also a reduction in $\mathrm{P}$ immobilization $(6.6 \%)$.

4. The grain yield and number of spikes of winter wheat demonstrated positive and medium strong correlation with the SMN. During the second year of the effect of the measures applied, wheat grain yield was significantly increased by white mustard cultivation $(4.9 \%)$ and mineral fertilisation $(\mathrm{SF}-55.3 \%$ and $\mathrm{IF}-$ $64.5 \%$ ), compared to the plots without catch crop and without fertiliser, respectively. The grain yield was mainly influenced by the number of spikes.

5. Intensification of fertilisation consistently increased accumulation of protein but reduced phosphorus $(\mathrm{P})$ and potassium $(\mathrm{K})$ contents in winter wheat grain. The straw retention resulted in significant increase in grain protein content in sustainable fertilisation treatment, but in a decrease in grain PK regardless of the fertilisation treatment. A positive effect of white mustard was found on grain $\mathrm{P}$ accumulation, but negative effect on grain $\mathrm{K}$ accumulation.

\section{Acknowledgments}

This work was part of the long-term research programme "Biopotential and quality of plants for multifunctional use" implemented by the Lithuanian Research Centre for Agriculture and Forestry.

Received 06022019

Accepted 11052020

\section{References}

1. Abid M., Tian Z., Ata-Ul-Karim S.T., Cui Y., Liu Y, Zahoor R., Jiang D., Dai T. 2016. Nitrogen nutrition improves the potential of wheat (Triticum aestivum L.) to alleviate the effects of drought stress during vegetative growth periods. Frontiers in Plant Science, 7: 981. https://doi.org/10.3389/fpls.2016.00981

2. Angus J. F., Kirkegaard J. A., Hunt J. R., Ryan M. H. Ohlander L., Peoples M. B. 2015. Break crops and rotations for wheat. Crop and Pasture Science, 66 (6) 523-552. https://doi.org/10.1071/CP14252

3. Arlauskienè A., Cesevičienė J., Velykis A. 2019 Improving mineral nitrogen control by combining catch crops, fertilisation, and straw management in a clay loam soil. Acta Agriculturae Scandinavica, Section B: Soil and Plant Science, 69 (5): 422-431.

https://doi.org/10.1080/09064710.2019.1593498

4. Balnytė S., Pupalienė R., Bogužas V. 2009. The importance of crop rotation, catch crop and manure in organic farming. Vagos, 84 (37): 7-11. http://asu.lt/wp-content uploads $/ 2015 / 03 /$ balnyte en.pdf

5. Bedoussac L., Journet E.-P., Hauggaard-Nielsen H., Naudin C., Corre-Hellou G., Jensen E. S., Prieur L., Justes E. 2015. Ecological principles underlying the increase of productivity achieved by cereal-grain legume intercrops in organic farming. A review. Agronomy for Sustainable Development, 35 (3): 911-935. https://doi.org/10.1007/s13593-014-0277-7

6. Cesco S., Mimmo T., Tonon G., Tomasi N., Pinton R., Terzano R., Neumann G., Weisskopf L., Renella G., Landi L., Nannipieri P. 2012. Plant-borne flavonoids released into the rhizosphere: impact on soil bio-activities related to plant nutrition. A review. Biology and Fertility of Soils, 48 (2): 123-149. https://doi.org/10.1007/s00374-011-0653-2

7. Cooper J. E., Scherer H. W. 2012. Nitrogen fixation. Marschner P. (ed.). Marschner's mineral nutrition of higher plants. Academic Press, p. 389-408.

https://doi.org/10.1016/B978-0-12-384905-2.00016-9

8. Ebrahimi E., Werren D., von Fragstein und Niemsdorff P. 2018. Suppressive effect of composts from residual biomass on Pythium ultimum. Journal of Plant Diseases and Protection, 125 (5): 443-449.

https://doi.org/10.1007/s41348-018-0163-7
9. Fuchs J. G., Thuerig B., Brandhuber R., Bruns C., Finckh M. R., Fließbach A., Mäder P., Schmidt H., VogtKaute W., Wilbois K.-P., Lucius T. 2014. Evaluation of the causes of legume yield depression syndrome using an improved diagnostic tool. Applied Soil Ecology, 79: 26-36. https://doi.org/10.1016/j.apsoil.2014.02.013

10. Gan Y., Hamel C., O'Donovan J. T., Cutforth H., Zentner R. P., Campbell C. A., Niu Y., Poppy L. 2015. Diversifying crop rotations with pulses enhances system productivity. Scientific Reports, 5: 14625. https://doi.org/10.1038/srep14625

11. Hauggaard-Nielsen H., Mundus S., Jensen E. S. 2009. Nitrogen dynamics following grain legumes and subsequent catch crops and the effects on succeeding cereal crops. Nutrient Cycling in Agroecosystems, 84 (3): 281-291. https://doi.org/10.1007/s10705-008-9242-7

12. Hegewald H., Wensch-Dorendorf M., Sieling K., Christen O. 2018. Impacts of break crops and crop rotations on oilseed rape productivity: a review. European Journal of Agronomy, 101: 63-77. https://doi.org/10.1016/j.eja.2018.08.003

13. Herridge D. F., Peoples M. B., Boddey R. M. 2008. Global inputs of biological nitrogen fixation in agricultural systems. Plant and Soil, 311 (1-2): 1-18 https://doi.org/10.1007/s11104-008-9668-3

14. Jannoura R., Joergensen R. G., Bruns C. 2014. Organic fertilizer effects on growth, crop yield, and soil microbial biomass indices in sole and intercropped peas and oats under organic farming conditions. Eurasian Journal of Agronomy, 52: 259-270.

https://doi.org/10.1016/j.eja.2013.09.001

15. Jensen E. S. 1991. Nitrogen accumulation and residual effects of nitrogen catch crops. Acta Agriculturae Scandinavica, 41 (4): 333-344. https://doi.org/10.1080/00015129109439917

16. Jensen E. S. 1997. Nitrogen immobilization and mineralization during initial decomposition of ${ }^{15} \mathrm{~N}$-labelled pea and barley residues. Biology and Fertility of Soils, 24 (1): 39-44. https://doi.org/10.1007/BF01420218

17. Jensen E. S., Peoples M. B., Hauggaard-Nielsen H. 2010 Faba bean in cropping systems. Field Crops Research, 115 (3): 203-216. https://doi.org/10.1016/j.fcr.2009.10.008

18. Jensen E. S., Bedoussac L., Carlsson G., Journet E. P., Justes E., Hauggaard-Nielsen H. 2015. Enchancing yields in organic crop production by eco-functional intensification. Sustainable Agriculture Research, 4 (3): 42-50. https://doi.org/10.5539/sar.v4n3p42

19. Jeuffroy M. H., Baranger E., Carrouée B., de Chezelles E., Gosme M., Hénault C., Schneider A., Cellier P. 2013. Nitrous oxide emissions from crop rotations including wheat, oilseed rape and dry peas. Biogeosciences, 10: 1787-1797. https://doi.org/10.5194/bg-10-1787-2013

20. Justes E., Mary B., Nicolardot B. 2009. Quantifying and modelling $\mathrm{C}$ and $\mathrm{N}$ mineralization kinetics of catch crop residues in soil: parameterization of the residue decomposition module of STICS model for mature and non mature residues. Plant and Soil, 325 (1-2): 171-185. https://doi.org/10.1007/s11104-009-9966-4

21. Langeveld J. W. A., Dixon J., Jaworski J. F. 2010. Development perspectives of the biobased economy: a review. Crop Science, 50 (1): 142-151. https://doi.org/10.2135/cropsci2009.09.0529

22. Li Y., Cui Z., Ni Y., Zheng M., Yang D., Jin M., Chen J., Wang Z., Yin Y. 2016. Plant density effect on grain number and weight of two winter wheat cultivars at different spikelet and grain positions. PLoS ONE, 11 (5): e0155351. https://doi.org/10.1371/journal.pone.0155351

23. Magrini M.-B., Anton M., Cholez C., Corre-Hellou G., Duc G., Jeuffroy M.-H., Meynard J.-M., Pelzer E., Voisin A.-S., Walrand S. 2016. Why are grain-legumes rarely present in cropping systems despite their environmental and nutritional benefits? Analyzing lock-in in the French agrifood system. Ecological Economics, 126: 152-162. https://doi.org/10.1016/j.ecolecon.2016.03.024

24. Meng Q. F., Yue S. C. Hou P., Cui Z. L., Chen X. P. 2016 Improving yield and nitrogen use efficiency simultaneously for maize and wheat in China: a review. Pedosphere, 26 (2): 137-147. https://doi.org/10.1016/S1002-0160(15)60030-3

25. O'Donovan J. T., Grant C. A., Blackshaw R. E., Harker K. N., Johnson E. N., Gan Y. G., Lafond G. P., May W. E., Turkington T. K., Lupwayi N. Z., Stevenson F. C., McLaren D. L., Khakbazan M., Smith E. G. 2014. Rotational effects of legumes and non-legumes on hybrid canola and malting barley. Agronomy Journal, 106 (6): 1921-1932. https://doi.org/10.2134/agronj14.0236 
26. Pilorgé E., Muel F. 2016. What vegetable oils and proteins for 2030? Would the protein fraction be the future of oil and protein crops? OCL - Oilseeds and Fats, Crops and Lipids, 23 (4): D402. https://doi.org/10.1051/ocl/2016030

27. Plaza-Bonilla D., Nolot J.-M., Passot S., Raffaillac D. Justes E. 2016. Grain legume-based rotations managed under conventional tillage need cover crops to mitigate soil organic matter losses. Soil and Tillage Research, 156: 33-43. https://doi.org/10.1016/j.still.2015.09.021

28. Preissel S., Reckling M., Schläfke N., Zander P. 2015. Magnitude and farm-economic value of grain legume precrop benefits in Europe: a review. Field Crops Research, 175: 64-79. https://doi.org/10.1016/j.fcr.2015.01.012

29. Raudonius S. 2017. Application of statistics in plant and crop research: important issues. Zemdirbyste-Agriculture, 104 (4): 377-382. https://doi.org/10.13080/z-a.2017.104.048

30. Reckling M., Hecker J.-M., Bergkvist G., Watson C. A., Zander P., Schläfke N., Stoddard F. L., Eory V., Topp C. F. E., Maire J., Bachinger J. 2016. A cropping system assessment framework - evaluating effects of introducing legumes into crop rotations. European Journal of Agronomy, 76: 186-197. https://doi.org/10.1016/j.eja.2015.11.005

31. Santín-Montanyá M. I., Zambrana E., Fernández-Getino A. P., Tenorio J. L. 2014. Dry pea (Pisum sativum L.) yielding and weed infestation response, under different tillage conditions. Crop Protection, 65: 122-128. https://doi.org/10.1016/j.cropro.2014.07.017

32. SiddiqueK.H.M.,JohansenC., TurnerN.C., Jeuffroy M.-H., Hashem A., Sakar D., Gan Y., Alghamdi S. S. 2012. Innovations in agronomy for food legumes. A review. Agronomy for Sustainable Development, 32 (1): 45-64. https://doi.org/10.1007/s13593-011-0021-5

33. Soon Y. K., Lupwayi N. Z. 2012. Straw management in a cold semi-arid region: impact on soil quality and crop productivity. Field Crop Research, 139: 39-46. https://doi.org/10.1016/j.fcr.2012.10.010
34. Tarakanovas P., Raudonius S. 2003. Agronominiu tyrimu duomenu statistinè analizè taikant kompiuterines programas ANOVA, STAT, SPLIT-PLOT is paketo SELEKCIJA ir IRRISTAT. Lithuanian University of Agriculture, 58 p. (in Lithuanian).

35. Terrile I. I., Miralles D. J., González F. G. 2017. Fruiting efficiency in wheat (Triticum aestivum $\mathrm{L}$ ): trait response to different growing conditions and its relation to spike dry weight at anthesis and grain weight at harvest. Field Crops Research, 201: 86-96. https://doi.org/10.1016/j.fcr.2016.09.026

36. Thorup-Kristensen K. 1994. The effect of nitrogen catch crop species on the nitrogen nutrition of succeeding crops. Fertilizer Research, 37 (3): 227-234. https://doi.org/10.1007/BF00748941

37. Toleikienè M., Brophy C., Arlauskienè A., Rasmussen J., Gecaitė V., Kadžiulienè Ž. 2019. Introduction of soybean in organic crop rotation: the impact on subsequent spring wheat productivity. Zemdirbyste-Agriculture, 106 (4): 321-330. https://doi.org/10.13080/z-a.2020.107.003

38. Voisin A.-S., Guéguen J., Huyghe C., Jeuffroy M.-H., Magrini M.-B., Meynard J.-M., Mougel C., Pellerin S., Pelzer E. 2014. Legumes for feed, food, biomaterials and bioenergy in Europe: a review. Agronomy for Sustainable Development, 34 (2): 361-380. https://doi.org/10.1007/s13593-013-0189-y

39. WRB. 2014. World reference base for soil resources. World Soil Resources Reports No. 106, FAO, p. 187-189.

40. Yan S., Wu Y., Fan J., Zhang F., Qiang S., Zheng J., Xiang Y., Guo J., Zou H. 2019. Effects of water and fertilizer management on grain filling characteristics, grain weight and productivity of drip-fertigated winter wheat. Agricultural Water Management, 213: 983-995. https://doi.org/10.1016/j.agwat.2018.12.019

41. Živanov D., Savić A., Katanski S., Karagić Đ., Milošević B., Milić D., Đorđević V., Vujić S., Krstić Đ., Cupina B. 2018. Intercropping of field pea with annual legumes for increasing grain yield production. Zemdirbyste-Agriculture, 105 (3): 235-242. https://doi.org/10.13080/z-a.2018.105.030

ISSN 1392-3196 / e-ISSN 2335-8947

Zemdirbyste-Agriculture, vol. 107, No. 3 (2020), p. 217-226

DOI $10.13080 /$ z-a.2020.107.028

\title{
Tarpinio pasėlio, šiaudų panaudojimo ir tręšimo įtaka augalų grandies žirniai $\rightarrow$ žieminiai kviečiai produktyvumui
}

\author{
A. Arlauskiene் $\dot{1}^{1}$ J. Cesevičienè2, A. Šlepetienè ${ }^{2}$ \\ ${ }^{1}$ Lietuvos agrarinių ir miškų mokslų centro Joniškèlio bandymų stotis \\ ${ }^{2}$ Lietuvos agrarinių ir miškų mokslų centro Žemdirbystès institutas
}

\section{Santrauka}

Žirnių ir kitų pupinių javų plotai didèja. Europos Sajunga skatina šių javų auginimą, siekiant sumažinti baltymų importą, naudoti mažiau trąšu ir tausoti aplinką. Taigi, pupinių javų auginimo technologijas reikia tobulinti, atnaujinti ir pritaikyti konkrečioms vietos sąlygoms. Tyrimo metu siekta nustatyti tarpinio pasèlio, javų šiaudų ir tręšimo intensyvumo ịtaką lauko žirnio (Pisum sativum L., pusiau belape forma) ir paprastojo kviečio (Triticum aestivum L., žieminè forma) produktyvumui ir cheminei sudèčiai giliau karbonatingame giliau glèjiškame sunkaus priemolio rudžemyje. Tirta sejjomainos grandis: vasarinis miežis (Hordeum vulgare L.) + baltosios garstyčios (Sinapis alba L.) posèlis arba be jo $\rightarrow$ žirniai $\rightarrow$ žieminiai kviečiai. Po derliaus nuèmimo vasarinių miežių šiaudai buvo išvežti iš lauko arba susmulkinti ir paskleisti $\left(+\mathrm{N}_{30}\right)$. Augalams trąšų normos apskaičiuotos remiantis tręšimo pagal dirvožemio agrocheminius rodiklius ir planuojamą derlių rekomendacijomis. Taikytas be trąšu, tausojantis ir intensyvus tręšimas. Trąšai panaudoti vasarinių miežių šiaudai $\left(+\mathrm{N}_{30}\right)$ pavasarị dirvožemyje lèmé esmingai didesnị (vidutiniškai $13 \%$ ) mineralinio N kieki, palyginti su šiaudais netręštu. Nustatyta neigiama esmine baltuju garstyčiu auginimo ir tręšimo sąveika su mineralinio azoto kiekiu dirvožemyje. Tai lèmè, kad pavasarị dirvožemyje mažejant mineralinio azoto kiekiui didejjo žirniu ankščiu skaičius, grūdu skaičius kvadratiniame metre, 1000 grūdu masè ir grūdų derlius. Didžiausia žalių baltymų koncentracija nustatyta žirnių grūduose, kai augintos baltosios garstyčios ir vasariniu miežiu šiaudai išvežti iš lauko. Antrais taikytu priemoniu poveikio metais esminès teigiamos itakos dirvožemio mineralinio azoto kiekiui turejo baltujjų garstyčių auginimas, šiaudų panaudojimas trąšai ir tręšimas mineralinėmis trąšomis. Žieminių kviečių grūdų derlių esmingai didino baltujų garstyčių auginimas $(4,9 \%)$ ir tręšimas mineralinèmis trąšomis (tausojantis tręšimas - 55,3\%, intensyvus tręšimas - 64,5\%). Žalių baltymų kiekiui didžiausią įtaką turèjo tręšimas mineralinėmis trąšomis.

Reikšminiai žodžiai: baltosios garstyčios, biometriniai rodikliai, derlius, mineralinis azotas, PK kiekis grūduose, žali baltymai. 